\title{
Mid-late Holocene event registered in organo-siliciclastic sediments of Lagoa Salgada carbonate system, southeast Brazil
}

\author{
Anna Paula Soares Cruz ${ }^{1}$, Cátia Fernandes Barbosa ${ }^{1}$, Angélica Maria Blanco ${ }^{1}$, Camila Areias de Oliveira $^{1}$, \\ Cleverson Guizan Silva ${ }^{2}$, and José Carlos Sícoli Seoane ${ }^{3}$ \\ ${ }^{1}$ Programa de Pós-Graduação em Geoquímica, Departamento de Geoquímica, Universidade Federal Fluminense, \\ Outeiro São João Batista, s/n, Centro, Niterói, Rio de Janeiro CEP 24.020-141, Brazil \\ ${ }^{2}$ Programa de Pós-Graduação em Dinâmica dos Oceanos e da Terra, Departamento de Geologia, \\ Universidade Federal Fluminense, Niterói, Rio de Janeiro, CEP 24.210-346, Brazil \\ ${ }^{3}$ Programa de Pós-Graduação em Geologia, Departamento de Geologia, Universidade Federal do Rio de Janeiro, \\ Rio de Janeiro, CEP 21.941-916, Brazil
}

Correspondence: Cátia Fernandes Barbosa (catiafb@id.uff.br)

Received: 27 February 2019 - Discussion started: 19 March 2019

Revised: 4 June 2019 - Accepted: 19 June 2019 - Published: 22 July 2019

\begin{abstract}
The formation of the Paraíba do Sul river delta plain on the coast of Rio de Janeiro state, Brazil, gave rise to diverse lagoons formed under different sea level regimes and climate variations. Sedimentary core lithology, organic matter geochemistry, and isotopic composition $\left({ }^{13} \mathrm{C}\right.$ and $\delta^{15} \mathrm{~N}$ ) were analyzed to interpret the sedimentation of the paleoenvironment of the Lagoa Salgada carbonate system. Different lithofacies reflect variations in the depositional environment. The abundance of silt and clay between 5.8 and $3.7 \mathrm{kyr}$ enhances the interpretation of a transgressive system, which promoted the stagnation of coarse sediment deposition due to coast drowning. Geochemistry data from this period (5.8-3.7 kyr) suggest the dominance of a wet climate with an increase of $\mathrm{C}_{3}$ plants and a marked dry event between 4.2 and $3.8 \mathrm{kyr}$. This dryer event also matches with previously published records from around the world, indicating a global event at $4.2 \mathrm{ka}$. Between 3.8 and $1.5 \mathrm{kyr}$, Lagoa Salgada was isolated; sand and silt arrived at the system by erosion with the retreat of the ocean and less fluvial drainage. Geochemistry from this moment marks the changes to favorable conditions for microorganisms active in the precipitation of carbonates, forming microbial mats and stromatolites in the drier phase.
\end{abstract}

\section{Introduction}

A severe and prolonged drought around the world characterizes the $4.2 \mathrm{ka}$ climatic event and is reflected in proxy records from North America (Booth et al., 2005; Bradley and Bakke, 2019), Asia (Perşoiu et al., 2019; Scuderi et al., 2019), Africa (Damnati et al., 2012; Gasse, 2000), South America (Tapia et al., 2003), the Arabian Sea (Giesche et al., 2019), and Antarctica (Staubwasser and Weiss, 2006). This significant aridification event in the mid-late Holocene is recognized in lake sequences; ice cores; and in speleothem, dust, and sediment samples. This drought was one of the most pronounced climatic events of the Holocene, after $8.2 \mathrm{ka}$, which was associated with the collapse of several human civilizations in many sites in the world such as in North Africa, the Middle East, and Asia (Cullen et al., 2000; Gasse, 2000; Weiss et al., 1993).

The 4.2 event has been the focus of several studies. However, the forcing mechanisms behind this event are still unknown. Some authors try to explain the drought and increase in aridity as a result of the weakening of the Asian monsoon (Giesche et al., 2019; Kathayat et al., 2018; Wang, 2005) due to the southward migration of the Intertropical Convergence Zone (ITCZ). Others suggest a prolonged northward shift of the mean position of the ITCZ (Li et al., 2018), being in contrast with the southward shift of the tropical rain belt. The irregular fluctuation of atmospheric pressure over the North Atlantic Ocean, changing the direction of the cy- 
clonic North Atlantic westerlies (Cullen et al., 2002; Kushnir and Stein, 2010), has been argued as another mechanism that results in megadrought around $4.2 \mathrm{ka}$, as well as the El Niño-Southern Oscillation (ENSO) conditions linked with drought in the monsoon region contributing to aridity in tropical South America during the same period (Davey et al., 2014).

In subtropical South America these events remain uncertain (Deininger et al., 2019), thus climate reconstructions in the region are essential to understand the geography of the changes in hydrological regimes. Southeastern Brazil is directly influenced by the convective rain belt of the South Atlantic Convergence Zone (SACZ), from the western Amazon to southeastern Brazil and the South Atlantic. The SACZ is the main component of the South American monsoon system (SAMS) (Jones and Carvalho, 2002), which is influenced by solar variability, enhancing evaporation and nearsurface moisture. This process is also reinforced by the southward movement of the Intertropical Convergence Zone (ITCZ) during periods of increased solar irradiance (Haug et al., 2001), strengthening the SAMS, and bringing moisture to southeastern Brazil via SACZ. Thus, paleoenvironmental studies in lakes and lagoons in coastal areas of southeastern Brazil constitute a powerful tool to understand the changes in the hydrological cycle throughout time.

Changes in the environmental conditions (wet or dry) are registered in lake sediment as well as the dynamics and processes that occurred in the water column. Some studies of lake systems have considered the stable isotopes of $\mathrm{C}$ and $\mathrm{N}$ in sediments as proxies of organic matter (OM) cycles in aquatic systems over time (Salomons and Mook, 1981). Other studies consider the vegetation changes as a result of the climate alteration (wet or dry conditions) (Rossetti et al., 2017) or still the environmental succession stages influenced by sedimentological processes and different communities of primary producers (Duarte et al., 2018). Many studies involving OM have been done to characterize past and recent depositional environments (Megens et al., 2002; Pessenda et al., 2004; Salomons and Mook, 1981). The percentage of total organic carbon (\% TOC) and the $\mathrm{C}: \mathrm{N}$ ratio can also indicate the productivity and OM sources in paleoclimatic interpretations (Hartmann and Wünnemann, 2009). Thus, the objectives of this work were to evaluate the depositional processes related to sea level changes during the marine and lacustrine stage and to interpret the Holocene climatic changes during the last $5.8 \mathrm{kyr}$. This work will contribute to the growing literature on the mid-late Holocene climate variability and environmental processes in South America.

\section{Material and methods}

Sediment core S-15 was sampled from Lagoa Salgada in Rio de Janeiro State, Brazil ( $\left.21^{\circ} 54^{\prime} 46.30^{\prime \prime} \mathrm{S}, 41^{\circ} 0^{\prime} 41.70^{\prime \prime} \mathrm{W}\right)$, recovering $212 \mathrm{~cm}$ length using a vibracore sampler (Fig. 1).
Samples were collected every $2 \mathrm{~cm}$ for total organic carbon $\left(\mathrm{C}_{\text {org }}\right)$ and carbon stable isotopes $\left(\delta^{13} \mathrm{C}_{\mathrm{org}}, \delta^{15} \mathrm{~N}\right)$ on bulk organic matter and every $4 \mathrm{~cm}$ for grain-size analysis. Sixteen samples throughout the core were analyzed for $\mathrm{Fe} / \mathrm{Ca}$ ratio. Due to the lack of preserved material in the majority of the core, except for a few individuals of Ammonia beccarii and Quinqueloculina seminulum, foraminiferal faunal assemblage was not considered. However, we compare our core with previously published data and respective authors are mentioned in Fig. 1 and Table 1.

\subsection{Radiocarbon and age model}

Radiocarbon analyses were performed at the Arizona Accelerator Mass Spectrometry Facility and BETA Analytic Inc., using ${ }^{14} \mathrm{C}$ accelerator mass spectrometry (AMS). The age model is based on 11 radiocarbon dates from organic material of bulk dried sediment samples and converted to calendar age (Table 2). Radiocarbon dates were calibrated using the R script BACON version 2.2 with IntCal 13 calibration curve to convert to calendar age. The parameters used were mem. mean $=0.7$, acc.shape $=0.8$, and t.a $=33$ and t. $\mathrm{b}=34$ (Fig. 2).

\subsection{Grain-size analysis}

About $2 \mathrm{~g}$ of dried sample was decarbonated using $\mathrm{HCl}$ for several hours, centrifuged, and washed with distilled water. Hydrogen peroxide $\left(\mathrm{H}_{2} \mathrm{O}_{2}\right)$ was also added to remove the organic matter. After these processes, about $30 \mathrm{~mL}$ of deflocculant solution $\left(\mathrm{Na}_{16} \mathrm{O}_{43} \mathrm{P}_{14}-4 \%\right)$ was added for $24 \mathrm{~h}$ (Barbosa, 1997). The grain-size measurements were performed using a laser particle analyzer (CILAS 1064) which has a detection range of $0.02-2000 \mu \mathrm{m}$, using the grain-size statistics method of Folk and Ward (1957) performed in GRADISTAT software version 8.0 (Blott and Pye, 2001).

\subsection{Total organic carbon and stable carbon and nitrogen isotopes in bulk organic matter}

Sediment samples for $\mathrm{C}_{\mathrm{org}}, \delta^{13} \mathrm{C}_{\mathrm{org}}$, and $\delta^{15} \mathrm{~N}$ were dried at $40^{\circ} \mathrm{C}$, powdered, and homogenized with an agate mortar. Samples were decalcified with a $1 \mathrm{~N} \mathrm{HCl}$ solution for several hours, centrifuged, washed with distilled water, and subsequently dried at $40^{\circ} \mathrm{C}$. About $30 \mathrm{mg}$ of the dried material was weighed in tin capsules and analyzed at the University of California Stable Isotope Facility (Davis, USA), using a MICRO cube elemental analyzer (Elementar Analysensysteme GmbH, Hanau, Germany.) interfaced to a PDZ Europa 20-20 isotope ratio mass spectrometer (Sercon Ltd., Cheshire, UK). The long-term standard deviation was $0.2 \%$ for $\delta^{13} \mathrm{C}_{\mathrm{org}}$. The $\delta^{13} \mathrm{C}_{\text {org }}$ were given as per mill in relation to Vienna Pee Dee Belemnite (VPDB) and the $\delta^{15} \mathrm{~N}$ were given as per mill in relation to the air. 

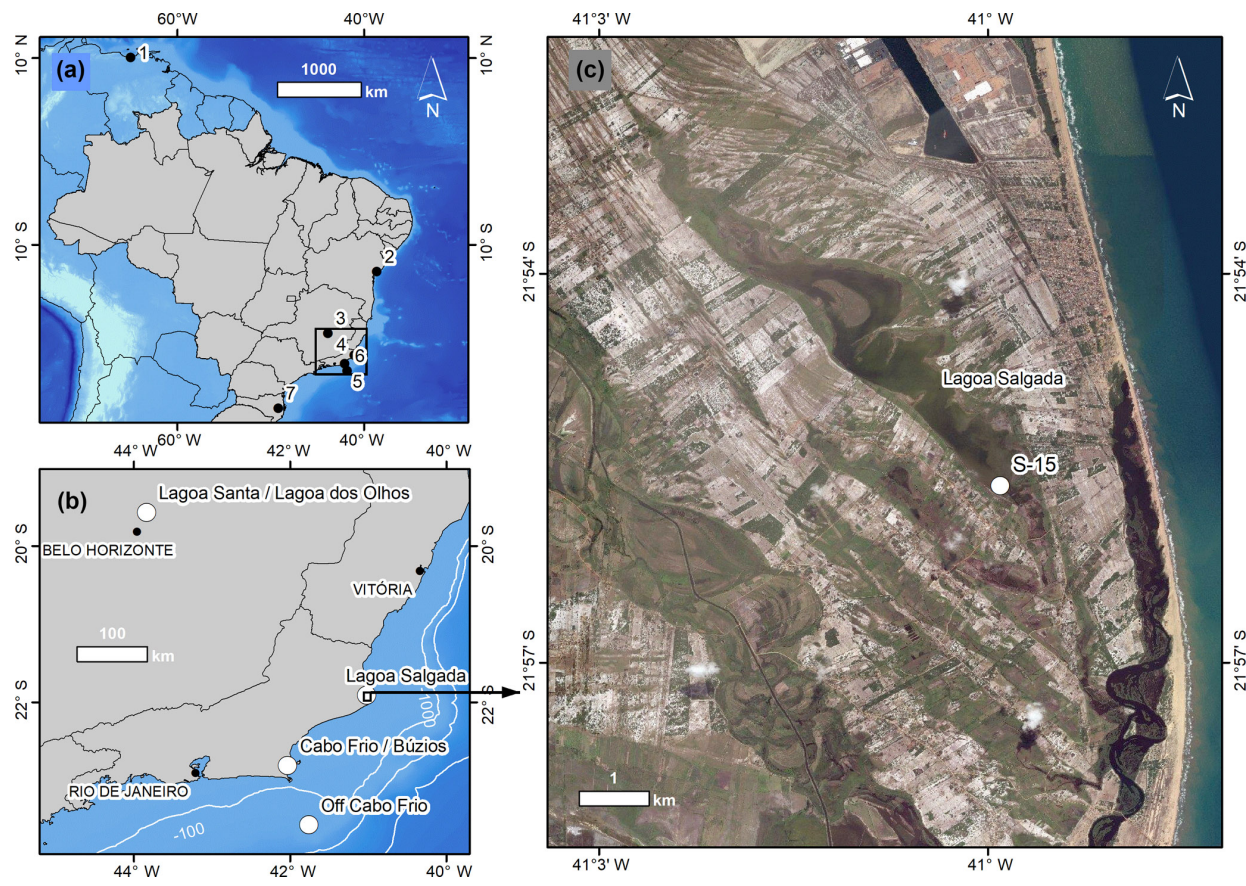

Figure 1. Location map of study area. (a) Brazil within South America. Black box indicates the location of (b). Numbers refer to sites mentioned in Table 1. (b) Southeastern Brazil with state capitals and sites mentioned in the text. (c) Location of core S-15 within Lagoa Salgada. Digital Globe image used as background. Note the seasonal low lake level. Image acquired 31 May 2017.

Table 1. Locations of published records cited.

\begin{tabular}{llrrl}
\hline No. & Region & Latitude & Longitude & Reference \\
\hline 1 & Cariaco Basin, Venezuela & 10.40 & -65.00 & Hughen et al. (1996) \\
2 & Salvador, BA, Brazil & -12.58 & -38.58 & Suguio et al. (1985) \\
3 & Lagoa Santa, MG, Brazil & -21.54 & -41.00 & Ledru et al. (1998) \\
4 & Lagoa Salgada, RJ, Brazil & -22.44 & -42.01 & This study \\
5 & Rio de Janeiro, RJ, Brazil & -23.20 & -41.74 & Castro et al. (2014) \\
6 & Cabo Frio/Búzios, RJ, Brazil & -27.22 & -49.16 & Lessa et al. (2016) \\
$*$ & Gulf of Oman & -24.39 & -59.04 & Cullen et al. (2000) \\
7 & Botuvera Cave, SC, Brazil & -27.22 & -49.16 & Bernal et al. (2016) \\
\hline
\end{tabular}

* Gulf of Oman is not presented on the map.

The carbon accumulation $\left(\mathrm{C}_{\text {org }}\right.$ accumulation) was determined using the following equation by Thunell et al. (1992), Eq. (1):

$C_{\text {org }}$ accumulation $\left(\mathrm{g} \mathrm{cm}^{-2} \mathrm{kyr}^{-1}\right)=\rho \mathrm{SR}\left(C_{\text {org }}\right)$,

where $\rho$ is density (in $\mathrm{g} \mathrm{cm}^{-3}$ ), SR is the sedimentation rate (in $\mathrm{cm} \mathrm{kyr}^{-1}$ ), and $\mathrm{C}_{\mathrm{org}}$ represents the total organic carbon content.

About $20 \mathrm{mg}$ of the sample was dried, crushed, and placed in a specific container to analyze the carbonate content. The analysis was performed every $2 \mathrm{~cm}$ using an inorganic carbon analyzer (TOC-V with ASI-V SSM 5000, Shimadzu).

\section{$2.4 \mathrm{Fe} / \mathrm{Ca}$ analysis}

$\mathrm{The} \mathrm{Fe} / \mathrm{Ca}$ analysis was performed on 16 dried and powdered samples using an X-ray fluorescence (XRF) spectrometer, Epsilon 3 (PANalytical), at the Universidade Federal Fluminense, Brazil.

\section{Results}

The sediment core S-15 recovered the last $5.8 \mathrm{kyr}$. The sedimentation rate ranged from 10 to $250 \mathrm{~cm} \mathrm{kyr}^{-1}$. Sedimentation rate increased between 5 to $4 \mathrm{kyr}$ (from 10 to $250 \mathrm{~cm} \mathrm{kyr}^{-1}$ ) with a posterior decrease during 4 to $3.7 \mathrm{kyr}$ (from 250 to $140 \mathrm{~cm} \mathrm{kyr}^{-1}$ ) and an increase between 3.7 and $3.5 \mathrm{kyr}$ (140 to $160 \mathrm{~cm} \mathrm{kyr}^{-1}$ ) (Fig. 2). 
Table 2. Ages, ${ }^{14} \mathrm{C}$, obtained from the dating of bulk organic matter to core S-15.

\begin{tabular}{lrrrrr}
\hline Lab ID & Depth $(\mathrm{cm})$ & ${ }^{14}$ C AMS ages & Error $(\mathrm{BP})$ & Age (cal BP) & Age $(2 \sigma$ ka cal BP) \\
\hline BETA363844 & 12 & 2750 & 30 & 2810 & 2.81 \\
BETA363846 & 16 & 3140 & 30 & 3244 & 3.24 \\
AA101944 & 22 & 3582 & 44 & 3613 & 3.61 \\
AA101946 & 38 & 3576 & 43 & 3723 & 3.72 \\
AA101947 & 56 & 3601 & 44 & 3829 & 3.83 \\
AA101948 & 72 & 3832 & 44 & 3942 & 3.94 \\
AA101951 & 110 & 3824 & 44 & 4099 & 4.10 \\
AA101953 & 138 & 3817 & 44 & 4220 & 4.22 \\
AA101955 & 166 & 3952 & 44 & 4496 & 4.50 \\
AA101956 & 196 & 4034 & 44 & 4735 & 4.74 \\
AA101957 & 210 & 5940 & 110 & 5779 & 5.78 \\
\hline
\end{tabular}

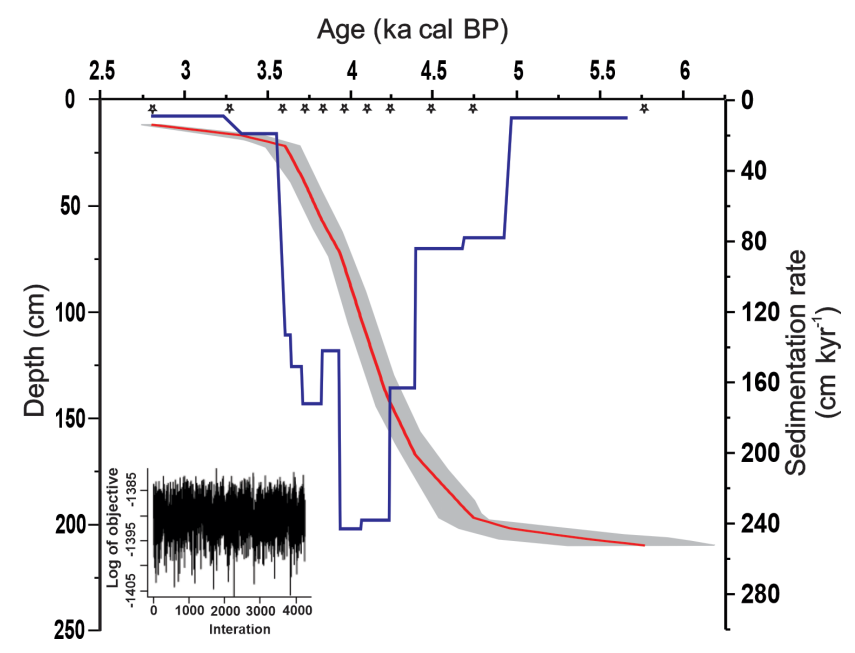

Figure 2. Bayesian age-depth model performed with BACON (Blaauw and Christeny, 2011) for the core S-15 (red line) and uncertainty (smooth gray curve) from Lagoa Salgada, Rio de Janeiro state, Brazil, with sedimentation rate $\left(\mathrm{cm} \mathrm{kyr}^{-1}\right)$ (blue line). Black stars indicate the position of the 11 radiocarbon dates measured. The inset shows the iteration history.

Grain-size analysis shows an increase in fine sediments, clay $(10 \%)$, and silt $(70 \%)$, between 5.8 and $3.7 \mathrm{kyr}$, with sand decreasing from $100 \%$ to $20 \%$. Between 3.7 and $0 \mathrm{kyr}$ the opposite trend occurred with an increase in sand grains $(\sim 84 \%)$ and a decrease in clay $(\sim 1 \%)$ and silt $(\sim 15 \%)$.

An increase in the $\mathrm{Fe} / \mathrm{Ca}$ ratio was observed ( 9 to 15 ) between 5.8 and $3.7 \mathrm{kyr}$ with a posterior decrease (15 to 4 ) toward the top. The iron and calcium alone showed an opposite trend with a decrease between 6 and $3.7 \mathrm{kyr}$, an increase between 3.7 and $3 \mathrm{kyr}$, and posterior decrease toward the top (Fig. 3).

Carbonate content showed an increase from $10 \%$ to $50 \%$ between 5.8 and $3.7 \mathrm{kyr}$. In the interval from 3.7 to $3 \mathrm{kyr}$, a decrease in the carbonate occurred (from $50 \%$ to $20 \%$ ) with a posterior increase toward the top $(\sim 80 \%)$ (Fig. $4 \mathrm{~b})$.

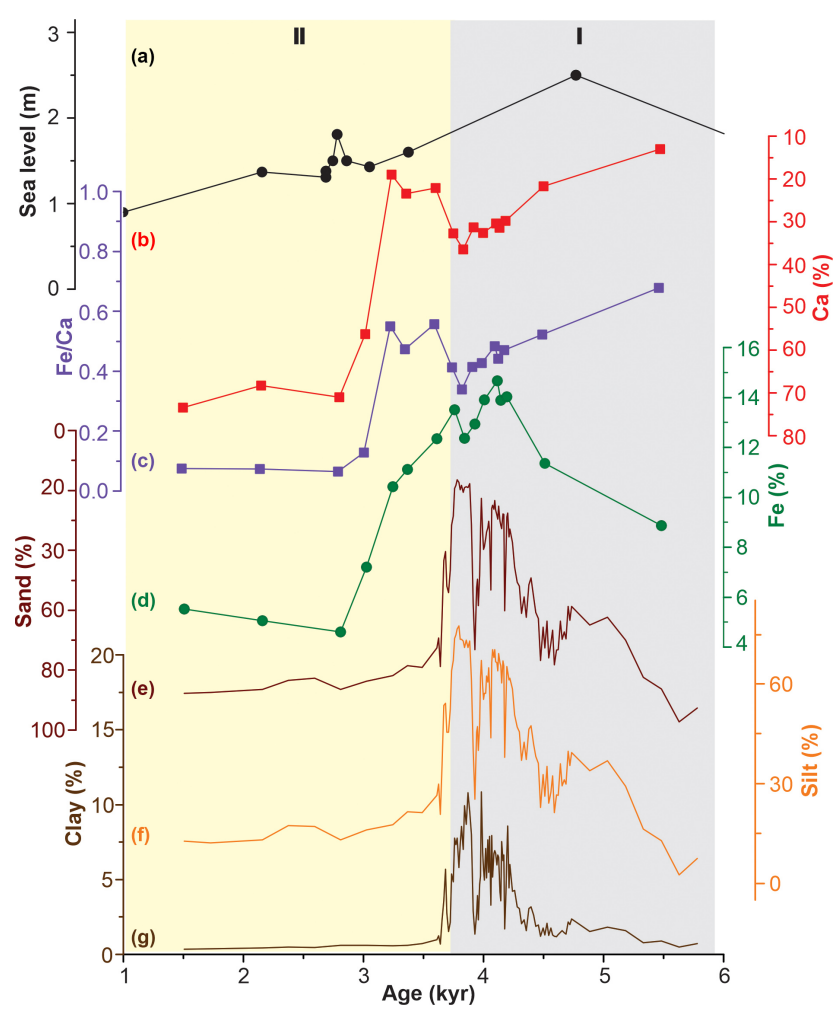

Figure 3. Comparison between sea level changes with sedimentologic records over the past $6 \mathrm{kyr}$. (a) Sea level (m) (Castro et al., 2014); (b) $\mathrm{Ca}(\%)$, (c) $\mathrm{Fe} / \mathrm{Ca}$, (d) $\mathrm{Fe}(\%)$, (e) sand (\%), (f) silt (\%), and (g) clay $(\%)$. The gray and yellow bars indicate two different stages in the last $6 \mathrm{kyr}$, marine (I) and lacustrine (II) stages, respectively.

The $\mathrm{C} / \mathrm{N}$ ratio ranged from 7 to 23 showing a variation between allochthonous and autochthonous organic material. Between 5.8 and $3.7 \mathrm{kyr}$ the mean value was around 13 . Between 3.7 and $3.2 \mathrm{kyr}$ an increase in the values $(\sim 18)$ occurred with a posterior decrease toward the present (Fig. 4c). 


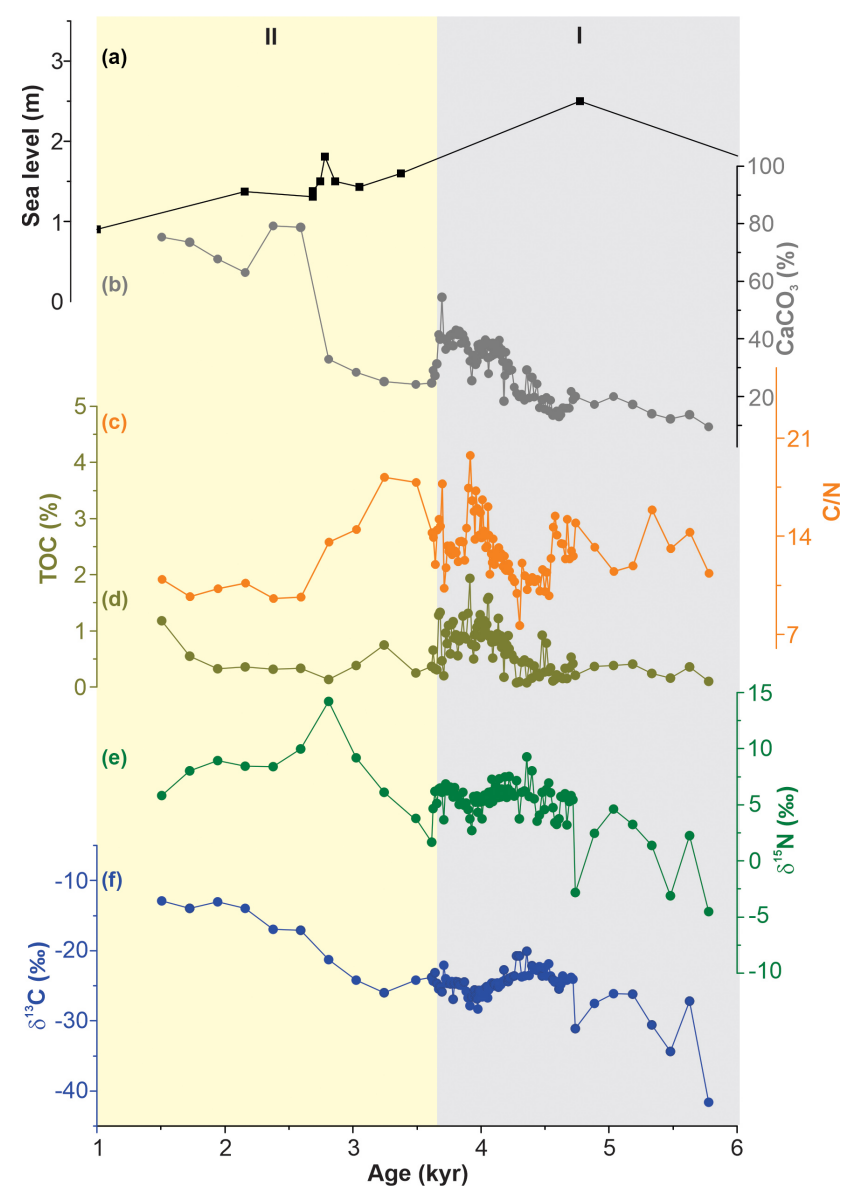

Figure 4. Comparison between sea level changes with geochemical records over the past $6 \mathrm{kyr}$. (a) Sea level (m) (Castro et al., 2014); (b) $\mathrm{CaCO}_{3}(\%)$, (c) $\mathrm{C} / \mathrm{N}$, (d) $\mathrm{TOC}(\%),(\mathbf{e}) \delta^{15} \mathrm{~N}(\%)$, and (f) $\delta^{13} \mathrm{C}$ $(\%)$. The gray and yellow bars indicate two different stages in the last $6 \mathrm{kyr}$, marine (I) and lacustrine (II) stages, respectively.

The total organic carbon ranged from $0.1 \%$ to $2 \%$ with an increase in the values between 4.7 and $3.7 \mathrm{kyr}$ (Fig. 4d). The $\delta^{15} \mathrm{~N}$ and $\delta^{13} \mathrm{C}$ showed the same trend increasing toward the present. The $\delta^{15} \mathrm{~N}$ ranged from $5 \%$ to $15 \%$ and $\delta^{13} \mathrm{C}$ ranged from $-40 \%$ o to $-12 \%$ o (Fig. 4 e, f).

\section{Discussion}

\subsection{Sedimentary processes}

Lagoa Salgada paleohydrodynamics shows two distinct stages during the mid-late Holocene. The first stage comprised the period between 5.8 and $3.7 \mathrm{kyr}$ (marine stage) and the second stage from 3.7 to $1.5 \mathrm{kyr}$ (lagoonal stage).

The marine stage ( 5.8 to $3.7 \mathrm{kyr}$ ) was characterized by a predominance of fine sediments (Fig. 3) and a gradual increase in the sediment deposition toward $3.7 \mathrm{ka}$ (Fig. 2). According to Castro et al. $(2014,2018)$ and Suguio et al. (1985), the maximum Holocene transgression occurred at $\sim 5 \mathrm{ka}$ when the sea level reached $\sim 3 \mathrm{~m}$ above the modern (Fig. 5a), causing the submergence of the coastal area. However, the evolution of the Paraíba do Sul river delta on the coastal plain formed the Lagoa Salgada initially as an intralagoonal system in a drowned coast around 3900 BP (Lemos, 1995).

In the first stage, the wet condition is dominant in almost all of the period, with a punctual change from 4.2 to $3.7 \mathrm{kyr}$. The gradual increase in the wet condition fed the river and increasing fine river discharge and organic material deposition (Figs. 3 and 4), indicating changes in the climate condition. The climate changes are inferred by the modification of vegetation type entering the system and in the source of material deposited (Fig. 4c, e, f). The S-15 core shows that between 5.8 and $3.7 \mathrm{kyr}$ the Lagoa Salgada was submerged within a drowning estuary and river flow stagnation occurred with fine sediment decantation in the environment during this period of high sea level (Fig. 3).

Low values of $\delta^{13} \mathrm{C}(\sim-25 \%)$ and high $\mathrm{C} / \mathrm{N}$ ratio from organic material (greater than 10) (Meyers, 1997) register an elemental contribution from cellulosic land plants $\left(\mathrm{C}_{3}\right)$ to the total organic matter input preserved in the sediments, which were less susceptible to degradation. The $\delta^{13} \mathrm{C}$ and $\mathrm{C} / \mathrm{N}$ ratio of the core $\mathrm{S}-15$ show the dominance of $\mathrm{C}_{3}$ plants between 5.8 and $4.8 \mathrm{kyr}$ with mixed sources between 4.8 and $3.7 \mathrm{kyr}$, when a small increase in $\delta^{15} \mathrm{~N}$ occurred, indicating a contribution of another source, such as phytoplankton $(\sim-19 \%)$ and $\mathrm{C}_{3}$ plants $(\sim-25 \%$ ) (Fig. $4 \mathrm{c}, \mathrm{f})$, within a period of humid conditions. The $\delta^{15} \mathrm{~N}$ shows the source and quality of the organic matter and the influence of terrestrial organic material during 5.8 to $4.8 \mathrm{kyr}$ (Fig. 4e). This influence is observed by low $\delta^{15} \mathrm{~N}$ values near to $0 \%$ (Schulz and Zabel, 1999), in which part of the nitrogen demand could come from atmospheric fixation. Unfortunately, nitrogen isotopes cannot discriminate between primary producers that overlap in carbon isotope values. While more detailed pollen analysis could be used to differentiate vegetation types and discriminate the sources of organic matter in sediment, isotopic composition values of Lagoa Salgada were in general consistent with pollen analyses made in cores collected from Lagoa Santa and Lagoa dos Olhos (Table 1), also in southeastern Brazil, showing the development of semideciduous forest. The increasing humidity favored the vegetation changes with the predominance of $\mathrm{C}_{3}$ plants during 7 to $4 \mathrm{kyr}$ (De Oliveira, 1992; Ledru et al., 1998).

Although there was an increase in iron in the sediments, indicating high terrestrial input, the $\mathrm{Fe} / \mathrm{Ca}$ ratio (Fig. 3c, d) shows an opposite trend. This difference occurred due to the highest amount of calcium deposited in the sediment floor compared to the iron input, which regulates the changes in the $\mathrm{Fe} / \mathrm{Ca}$ ratio in this environment. The iron input also promoted an increase in the primary productivity and, consequently, the increase in calcium carbonate during the first stage (Figs. 3c and $4 b$ ).

The second stage comprised the period between 3.7 and $1.5 \mathrm{kyr}$. The formation of the sandy barrier caused by sea 

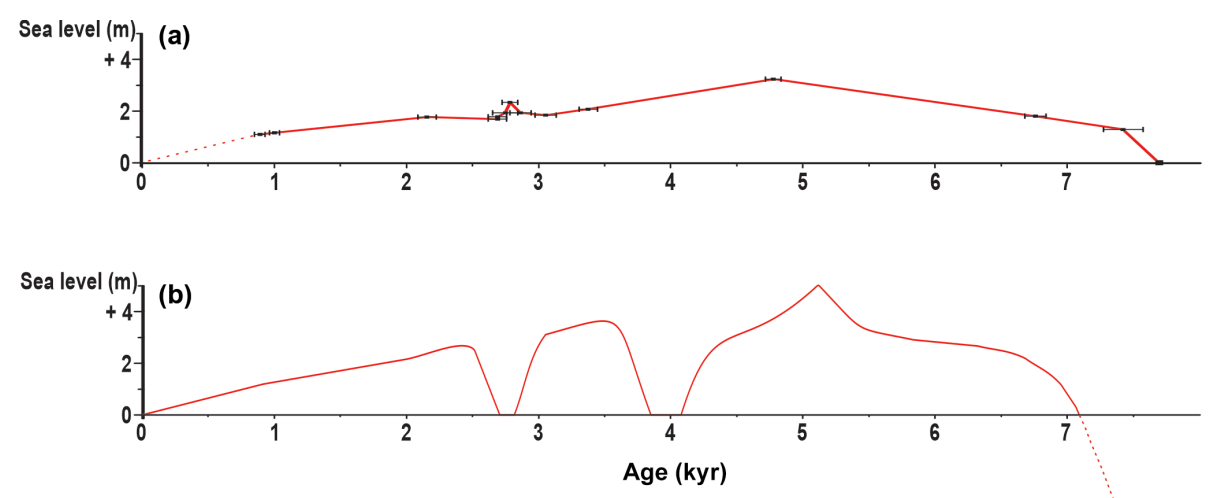

Figure 5. Relative sea-level variation curve for (a) the coast of the Rio de Janeiro state, Brazil (Castro et al., 2014), and (b) Salvador, Bahia state, Brazil (Martin and Suguio, 1992).

transgression favored the creation of lagoonal systems in the delta. During this stage coarse sediments predominate (sand) $(\sim 84 \%)$. The $\mathrm{Fe} / \mathrm{Ca}$ ratio was low with a considerable increase in calcium percentage $(\sim 80 \%)$ (Fig. 3$)$. According to Castro et al. (2014), a rapid marine regression occurred between 5.5 and $4.5 \mathrm{kyr}$. In the $\mathrm{S}-15$ core, marine regression is identified after $3.7 \mathrm{ka}$ when the lake was formed, allowing the input of coarse sediments by erosion with the retreat of the ocean. Lemos (1995) indicated the ages of lake formation at about 2000 and between 3090 and 3900 BP, respectively. The approximate ages were estimated from different strata of the stromatolites at the edge of the lake.

Geomorphological characteristics and seasonal variability modified the geochemistry of the lake, influencing the sedimentation and precipitation of salts and carbonates that formed biosedimentary structures of stromatolites, thrombolites, and oncoids (Silva e Silva et al., 2005, 2008).

Carbonate content shows an increase during the second stage as a result of the increasing biological productivity in the lake, while the $\mathrm{C} / \mathrm{N}$ ratio shows mixing between terrestrial plants and phytoplankton as the organic source with decreasing values $(\sim 10) ; \delta^{15} \mathrm{~N}$ and $\delta^{13} \mathrm{C}$ also indicate different sources of organic matter. In this stage, $\delta^{15} \mathrm{~N}$ and $\delta^{13} \mathrm{C}$ increase towards the top of the core, characterizing changes in vegetation with dominance of $\mathrm{C}_{4}$ plants. $\mathrm{A} \mathrm{C}_{4}$ plant signature at the top of the core (around 2 to $1.5 \mathrm{kyr}$ ), evidenced by increasing $\delta^{13} \mathrm{C}(\sim-10 \%)$, was also observed by França et al. (2016) and Ledru et al. (1998) in cores collected in lakes from southeastern Brazil, showing a replacement of tropical semideciduous forests by herbaceous vegetation, indicating a relatively dry climate during this period. The climate condition at this time could be influenced by the upwelling system (Laslandes et al., 2006; Nagai et al., 2009, 2016), which favors increasing ocean-land temperature gradient typical of semiarid climates, corroborating the dominance of $\mathrm{C}_{4}$ plants. The input of saltwater into the coastal wetland and the formation of coastal dunes also can trigger the development of plant communities dominated by $\mathrm{C}_{4}$ species as a result of the competitive advantages of salt-tolerant species, promoting a regressive succession of vegetation not necessarily influenced by climate changes (Zhou et al., 2018). However, pollen data from cores collected from freshwater lakes in southeastern Brazil (Behling, 1995, 1998; Ledru et al., 1998), with no influence of coastal dynamics, also show changes in vegetation resulting from climate alterations throughout the Holocene. Thus, we consider climate to be the main cause of the changes in vegetation dominance, resulting in the isotopic alteration of the organic matter.

The abrupt change in proxy values in the second stage of the lake show that local climate and the proliferation of microbial communities have modified the geochemistry of the lake and its sedimentation. High $\delta^{15} \mathrm{~N}$ values also suggest metabolism related to the development of the microorganisms, which gave rise to the stromatolites present in the Lagoa Salgada. The presence of gastropods caused bioturbation in the sediments, affecting the microbial processes and altering the physicochemical properties of the sediment, by favoring the entry of $\mathrm{O}_{2}$ at the water-sediment interface and $\mathrm{N}$ fixation stimulating denitrification (Laverock et al., 2011).

Some species of cyanobacteria have the ability to live in the mud of hypersaline environments and they are halophilic, alkaline (Dupraz et al., 2009), and precipitate carbonates (Xu et al., 2006). Silva et al. (2013) identified 21 species of cyanobacteria in stromatolites of the Lagoa Salgada, with the most representative being Microcoleus chthonoplastes and Lyngbya aestuarii, which are diazotrophic cyanobacteria present in coastal microbial mats. In hypersaline lakes, such as Lagoa Salgada, microbial mats precipitate $\mathrm{CaCO}_{3}$ as a by-product of $\mathrm{CO}_{2}$ capture through photosynthesis by cyanobacteria (Jonkers et al., 2003; Ludwig et al., 2005). The precipitation of $\mathrm{CaCO}_{3}$ that generated the lithification of the microbial mats in the lake are caused by cyanobacteria that increase the $\mathrm{pH}$ through photosynthesis in a $\mathrm{CaCO}_{3}$ supersaturated system (Decho and Kawaguchi, 2003).

Radiocarbon dating by Coimbra et al. (2000) in the stromatolite head of the Lagoa Salgada shows the growth of 
these structures to have begun around $2200 \pm 80 \mathrm{BP}$ and finished around $290 \pm 80 \mathrm{BP}$. They noticed differences in growth rates of stromatolite relating to the organization of the structure, being better structured at the middle of the head than at the top of the structure, with an average growth rate of $0.05 \mathrm{~mm} \mathrm{yr}^{-1}$. In the case of the Lagoa Salgada, changes in the environmental dynamics and the development of microbial communities after isolation of the marine influence, shown by changes in vegetation type $\left(\mathrm{C}_{4}\right.$ plants $)$ and an increase in $\mathrm{CaCO}_{3}$ values $(80 \%)$, influence the appearance of the stromatolites at around $2800 \pm 8 \mathrm{BP}$.

\subsection{The 4.2 event}

During the transgressive stage (5.8 to $3.7 \mathrm{kyr}$ ) differences in climate conditions are observed in southeastern Brazil (Fig. 6).

Geochemistry data show an increase in productivity between 5 and $4.2 \mathrm{kyr}$ with increasing carbonate and organic carbon percentages (Fig. 6d). The enrichment of organic carbon in the sediment floor is also related to increasing deposition of fine sediments (Fig. 6e), which have the ability to adsorb electrolytes and organic material (Busch and Keller, 1981; Cruz et al., 2013, 2018), thus changing the composition of the sediments.

The wet condition of the environment during this period (5-4.2 kyr) was characterized by high carbon accumulation and predominance of $\mathrm{C}_{3}$ plants (Fig. 4d, f). High humidity during this period is also characterized by decreasing $\mathrm{Mg} / \mathrm{Ca}$ ratios in speleothems collected in the Botuvera Cave, southeastern Brazil (Bernal et al., 2016) (Fig. 6g). In that study, Bernal et al. (2016) suggest that most of the changes in rainfall patterns during the Holocene were driven by the intensity of the South Atlantic Monsoon Summer (SAMS). SAMS intensification, influenced by the South Atlantic Convergence Zone (SACZ), protrudes as a lower troposphere convective rain belt from the western Amazon to southeastern Brazil and the South Atlantic (Gandu and Silva Dias, 1998). The precipitation response also results from an adjustment of the Intertropical Convergence Zone (ITCZ), which displaces itself according to cooling in the Northern Hemisphere and changes in the interhemispheric sea surface temperature (SST) (Cvijanovic et al., 2013). The anomalous southward displacement of the ITCZ shown by dry conditions in the Cariaco Basin (Hughen et al., 1996) (Fig. 6a) indicates increased wet conditions during the transition from the middle to the early Holocene in the Southern Hemisphere.

Higher sand fraction and lower carbonate and iron contents reveal a significant change in the environmental conditions during the interval of $4.2-3.8 \mathrm{kyr}$, which could be a regional manifestation of the $4.2 \mathrm{ka}$ event in southeastern Brazil. Dry conditions could affect the local vegetation (the mixture of sources shown in Fig. 4f) which leads to the reduction of dense vegetation $\left(\mathrm{C}_{3}\right.$ plants), increasing erosion and consequently the accumulation of coarser materials. The

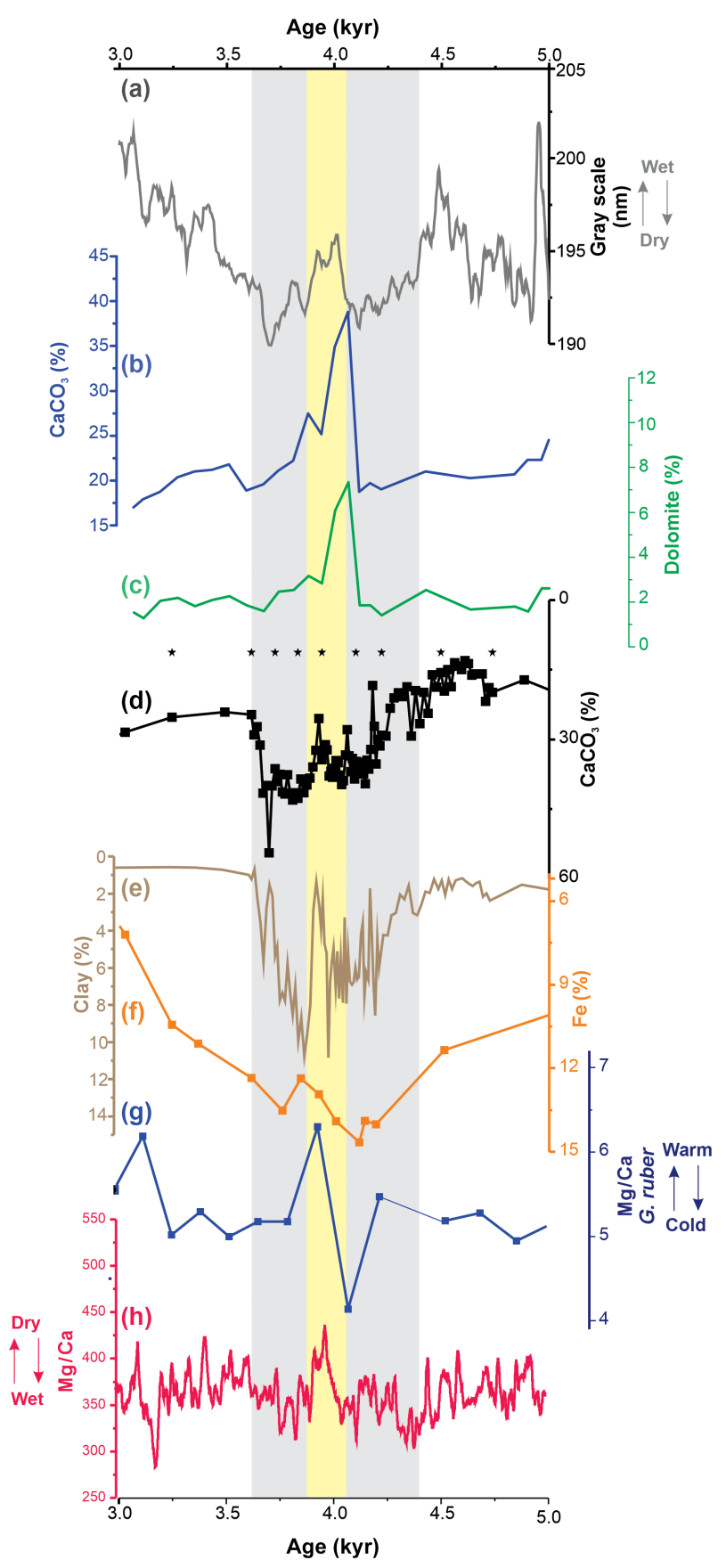

Figure 6. Geochemical records from Lagoa Salgada in comparison with other climate records. (a) Gray scale (nm) from Cariaco Basin, Venezuela (Hughen et al., 1996); (b) Carbonate content $\left(\mathrm{CaCO}_{3}\right)(\%)$ and (c) dolomite $(\%)$ from the Gulf of Oman (Cullen et al., 2000); (d) Carbonate content $\left(\mathrm{CaCO}_{3}\right)(\%)$, (e) clay (\%), and (f) $\mathrm{Fe}(\%)$ from this study; (g) $\mathrm{Mg} / \mathrm{Ca}$, Globigerinoides ruber, from the southwest Brazilian coast (Lessa et al., 2016) and (h) $\mathrm{Mg} / \mathrm{Ca}$ speleothem from Botuvera Cave, southwestern Brazil (Bernal et al., 2016). The nine black stars indicate the position of the radiocarbon dates measured in this study. The gray bar emphasizes the period between 4.3 and $3.6 \mathrm{kyr}$ (wet condition) and the yellow bar shows the 4.2 ka event (dry condition). 
drought would be caused by a reduction of the intensity of the SAMS and the possible northward displacement of the ITCZ, shown by increasing wet conditions in Cariaco Basin (Fig. 6a) and drier conditions for the Botuvera Cave in southeastern Brazil (Fig. 6g). In addition, the northward migration of the ITCZ could also have caused the weakening of the upwelling system in southeastern Brazil. Upwelling during this period became limited to the subsurface with warm conditions on the surface waters, shown by increasing $\mathrm{Mg} / \mathrm{Ca}$ ratio in planktonic foraminifera (Globigerinoides ruber) (Fig. 6f) (Lessa et al., 2016).

Several other paleoarchives recovered around Asia (Giesche et al., 2019; Kaniewski et al., 2018; Kathayat et al., 2018; Scuderi et al., 2019), Europe (Isola et al., 2019; Zanchetta et al., 2016), and Africa (Gasse, 2000) show this drier event between 4.2 and $3.8 \mathrm{kyr}$. Arz et al. (2006) suggested that the environmental changes around $4.2 \mathrm{ka}$ is an expression of a major drought event, which strongly affected the Middle Eastern agricultural civilizations. A sediment core recovered in the Gulf of Oman showed a rather abrupt signature with climate changes around $4.2 \mathrm{ka}$ (Cullen et al., 2000) and a prominent spike of $\mathrm{CaCO}_{3}$ and dolomite indicating the aridity (Fig. 6b, c) during the same dry period shown by the S-15 core indicating it may correspond to a global event.

The increase in the sand fraction in core S- 15 also can be explained by an erosional phase that changed local hydrodynamics, leading to an increase in the coarse deposition as the consequence of a regression of the sea level (Fig. 5b) (Martin and Suguio, 1992). This regression also allowed the deposition of terrestrial organic material, shown by an increase in $\mathrm{C} / \mathrm{N}$ ratio (Fig. 4c) and a decrease in $\delta^{15} \mathrm{~N}$ and $\delta^{13} \mathrm{C}$ (Fig. $4 \mathrm{e}, \mathrm{f}$ ), causing a decrease in the carbonate accumulation (Fig. 4b). According to Martin and Suguio (1992), the abrupt fall in sea level, between about 4200 and $3900 \mathrm{BP}$, provoked an oceanward exit of active distributaries of the intralagoonal delta. However, the lack of data during this period, in both sea level curves (Castro et al., 2014; Martin and Suguio, 1992), make this hypothesis of sea level regression merely speculative and the influence of climate change a more plausible alternative to the environmental changes that occurred during this period.

Between 3.9 and $3.7 \mathrm{kyr}$, a return to the same environmental conditions before the event is observed with increasing humidity. This period may also have been marked by a new marine transgression, which prevented terrestrial deposition in the study area (Martin and Suguio, 1992).

\section{Conclusions}

The paleohydrodynamics of Lagoa Salgada shows a clear adjustment with variation in the sea level. During the period of the sea level transgression (5.8 to $3.7 \mathrm{kyr}$ ), Lagoa Salgada was submerged, promoting the drowning of a river and the stagnation of coarse sediment contribution, thus increasing decantation of fine sediment and organic material deposition. This period was also characterized by the dominance of $\mathrm{C}_{3}$ plants and an increase in the sedimentation rate, indicating wetter conditions.

During the transgressive stage ( 5.8 to $3.7 \mathrm{kyr}$ ), a significant change in climate conditions occurred resulting in a period of aridification, from 4.2 to $3.7 \mathrm{kyr}$. The period between 4.2 and $3.7 \mathrm{kyr}$ was also characterized by changes in the local vegetation, with a reduction of $\mathrm{C}_{3}$ plants and the accumulation of coarse sediments due to increasing erosion. The drought would be caused by a reduction in the intensity of the SAMS due to the northward displacement of the ITCZ.

The regression of the sea level (3.7 ka to present) promoted the evolution of the Paraíba do Sul river delta on the coastal plain and the formation of the lake system. The lake was formed allowing the input of coarse sediments by erosion with the retreat of the ocean. Abrupt modification in the vegetation type and in the sedimentary deposits was observed in this period with a dominance of $\mathrm{C}_{4}$ plants and a decrease in the sedimentation rate, indicating a predominance of dry conditions on the environment. With the closure of the Lagoa Salgada by the sandy ridges of the delta, geochemical modifications generated internally in the lake and allowed the appearance of microbial carpets and stromatolites after $2.8 \mathrm{ka}$.

Data availability. The data that support the findings of this study are available from the corresponding author upon reasonable request.

Author contributions. APSC and CFB designed the study and wrote and reviewed the paper. AMB and CAO performed data analyses. CGS provided financial support for this work. JCSS revised and edited the paper.

Competing interests. The authors declare that they have no conflict of interest.

Acknowledgements. We thank the editor Alessio Rovere and the anonymous reviewers for their comments and suggestions.

We thank the support of project "Stratigraphic, Sedimentological and Geochemical Characterization of Lagoas Salgada, Vermelha and Brejo do Espinho", (PETROBRAS-CENPES). Anna Paula Soares Cruz thanks CNPq, process no. 153418/2016-8. This study was financed in part by the Coordenação de Aperfeiçoamento de Pessoal de Nível Superior - Brazil (CAPES) - Finance Code 001.

Financial support. This research has been supported by the Project PETROBRAS CENPES (Stratigraphic, Sedimentological and Geochemical Characterization of Lagoas Salgada, Vermelha 
and Brejo do Espinho, grant no. FEC 2979), CNPq (process no. 153418/2016-8) and Coordenação de Aperfeiçoamento de Pessoal de Nível Superior - Brazil (CAPES, Finance Code 001).

Review statement. This paper was edited by Alessio Rovere and reviewed by two anonymous referees.

\section{References}

Arz, H. W., Lamy, F., and Pätzold, J.: A pronounced dry event recorded around $4.2 \mathrm{ka}$ in brine sediments from the northern Red Sea, Quaternary Res., 66, 432-441, https://doi.org/10.1016/j.yqres.2006.05.006, 2006.

Barbosa, C. F.: Reconstituição paleoambiental de fácies lagunares com base em foraminiferos: O nível do mar no Quaternário Superior na área de Cabo Frio, RJ, Universidade de São Paulo, Instituto de Geociências, 278 pp., 1997.

Behling, H.: A high resolution Holocene pollen record from Lago do Pires, SE Brazil: vegetation, climate and fire history, J. Paleolimnol., 14, 253-268, https://doi.org/10.1007/BF00682427, 1995.

Behling, H.: Late Quaternary vegetational and climatic changes in Brazil, Rev. Palaeobot. Palyno., 99, 143-156, https://doi.org/10.1016/S0034-6667(97)00044-4, 1998.

Bernal, J. P., Cruz, F. W., Stríkis, N. M., Wang, X., Deininger, M., Catunda, M. C. A., Ortega-Obregón, C., Cheng, H., Edwards, R. L., and Auler, A. S.: High-resolution Holocene South American monsoon history recorded by a speleothem from Botuverá Cave, Brazil, Earth Planet. Sc. Lett., 450, 186-196, https://doi.org/10.1016/j.epsl.2016.06.008, 2016.

Blaauw, M. and Christeny, J. A.: Flexible paleoclimate age-depth models using an autoregressive gamma process, Bayesian Anal., 6, 457-474, https://doi.org/10.1214/11-BA618, 2011.

Blott, S. J. and Pye, K.: GRADISTAT: a grain size distribution and statistics package for the analysis of unconsolidated sediments, Earth Surf. Process. Land., 26, 1237-1248, https://doi.org/10.1002/esp.261, 2001.

Booth, R. K., Jackson, S. T., Forman, S. L., Kutzbach, J. E., Bettis, E. A., Kreig, J., and Wright, D. K.: A severe centennialscale drought in mid-continental North America 4200 years ago and apparent global linkages, Holocene, 15, 321-328, https://doi.org/10.1191/0959683605hl825ft, 2005.

Bradley, R. and Bakke, J.: Is there evidence for a $4.2 \mathrm{ka} \mathrm{BP}$ event in the northern North Atlantic region?, Clim. Past Discuss., https://doi.org/10.5194/cp-2018-162, in review, 2019.

Busch, W. H. and Keller, G. H.: The physical properties of PeruChile continental margin sediments-the influence of coastal upwelling on sediment, J. Sediment. Petrol., 51, 705-719, 1981.

Castro, J. W. A., Suguio, K., Seoane, J. C. S., Cunha, A. M., and Dias, F. F.: Sea-level fluctuations and coastal evolution in the state of Rio de Janeiro, southeastern Brazil, An. Acad. Bras. Cienc., 86, 671-683, https://doi.org/10.1590/0001$3765201420140007,2014$.

Castro, J. W. A., Seoane, J. C. S., Cunha, A. M. D. A., Malta, J. V., Oliveira, C. A., Vaz, S. R., and Suguio, K.: Comments to Angulo et al. 2016 on "Sea-level fluctuations and coastal evolution in the state of Rio de Janeiro, southeastern - Brazil" by Castro et al. 2014, An. Acad. Bras. Cienc., 90, 1369-1375, https://doi.org/10.1590/0001-3765201820171010, 2018.

Coimbra, M. M., Silva, C. G., Barbosa, C. F., and Mueller, K. A.: Radiocarbon measurements of stromatolite heads and crusts at the Salgada Lagoon, Rio de Janeiro State, Brazil, Nucl. Instrum. Meth. B, 172, 592-596, https://doi.org/10.1016/S0168583X(00)00391-8, 2000.

Cruz, A. P. S., Barbosa, C. F., Ayres-Neto, A., and Albuquerque, A. L. S.: Physical and geochemical properties of centennial marine sediments of the continental shelf of southeast Brazil, Geochim. Bras., 27, 1-12, https://doi.org/10.5327/Z0102$9800201300010001,2013$.

Cruz, A. P. S., Barbosa, C. F., Ayres-Neto, A., Munayco, P., Scorzelli, R. B., Amorim, N. S., Albuquerque, A. L. S., and Seoane, J. C. S.: Geochemistry and magnetic sediment distribution at the western boundary upwelling system of southwest Atlantic, Cont. Shelf Res., 153, 64-74, https://doi.org/10.1016/j.csr.2017.12.011, 2018.

Cullen, H. M., DeMenocal, P. B., Hemming, S., Hemming, G., Brown, F. H., Guilderson, T. P., and Sirocko, F.: Climate change and the collapse of the Akkadian empire: Evidence from the deep sea, Geology, 28, 379-382, 2000.

Cullen, H. M., Kaplan, A., Arkin, P. A., and DeMenocal, P. B.: Impact of the North Atlantic Oscilation on middle eastern climate and streamflow, Climatic Change, 55, 315-338, https://doi.org/10.1023/A:1020518305517, 2002.

Cvijanovic, I., Langen, P. L., Kaas, E., and Ditlevsen, P. D.: Southward intertropical convergence zone shifts and implications for an atmospheric bipolar seesaw, J. Climate, 26, 41214137, https://doi.org/10.1175/JCLI-D-12-00279.1, 2013.

Damnati, B., Etebaai, I., Reddad, H., Benhardouz, H., Benhardouz, O., Miche, H., and Taieb, M.: Recent environmental changes and human impact since mid-20th century in Mediterranean lakes: Ifrah, Iffer and Afourgagh, Middle Atlas Morocco, Quaternary Int., 262, 44-55, https://doi.org/10.1016/j.quaint.2011.09.028, 2012.

Davey, M. K., Brookshaw, A., and Ineson, S.: The probability of the impact of ENSO on precipitation and near-surface temperature, Clim. Risk Manag., 1, 5-24, https://doi.org/10.1016/j.crm.2013.12.002, 2014.

Decho, A. W. and Kawaguchi, T.: Extracellular Polymers (EPS) and calcification within modern marine stromatolites, in: Fossil and Recent Biofilms - A natural History of life on Earth, 227-240, Springer Netherlands, Dordrecht, 2003.

Deininger, M., Ward, B. M., Novello, V. F., and Cruz, F. W.: Late Quaternary Variations in the South American Monsoon System as Inferred by Speleothems - New Perspectives using the SISAL Database, Quaternary, 2, 6, https://doi.org/10.3390/quat2010006, 2019.

De Oliveira, P. E.: A palynological record of late Quaternary vegetational and climatic change in southeastern Brazil, Ohio State University, 1992.

Duarte, C. M., Delgado-Huertas, A., Anton, A., Carrillo-deAlbornoz, P., López-Sandoval, D. C., Agustí, S., Almahasheer, H., Marbá, N., Hendriks, I. E., Krause-Jensen, D., and GarciasBonet, N.: Stable Isotope $\left(\delta^{13} \mathrm{C}, \delta^{15} \mathrm{~N}, \delta^{18} \mathrm{O}, \delta \mathrm{D}\right)$ Composition and Nutrient Concentration of Red Sea Primary Producers, Front. Mar. Sci., 5, 1-12, https://doi.org/10.3389/fmars.2018.00298, 2018. 
Dupraz, C., Reid, R. P., Braissant, O., Decho, A. W., Norman, R. S., and Visscher, P. T.: Processes of carbonate precipitation in modern microbial mats, Earth-Sci. Rev., 96, 141-162, https://doi.org/10.1016/j.earscirev.2008.10.005, 2009.

Folk, R. L. and Ward, W. C.: Brazos river bar: study of the significance of grain size parameters, J. Sediment. Petrol., 17, 3-27, 1957.

França, M. C., Alves, I. C. C., Cohen, M. C. L., Rossetti, D. F., Pessenda, L. C. R., Giannini, P. C. F., Lorente, F. L., Buso Junior, A. Á., Bendassolli, J. A., and Macario, K.: Millennial to secular time-scale impacts of climate and sea-level changes on mangroves from the Doce River delta, Southeastern Brazil, Holocene, 26, 1733-1749, https://doi.org/10.1177/0959683616645938, 2016.

Gandu, A. W. and Silva Dias, P. L.: Impact of tropical heat sources on the South American tropospheric upper circulation and subsidence, J. Geophys. Res.-Atmos., 103, 6001-6015, https://doi.org/10.1029/97JD03114, 1998.

Gasse, F.: Hydrological changes in the African tropics since the Last Glacial Maximum, Quaternary Sci. Rev., 19, 189-211, https://doi.org/10.1016/S0277-3791(99)00061-X, 2000.

Giesche, A., Staubwasser, M., Petrie, C. A., and Hodell, D. A.: Indian winter and summer monsoon strength over the $4.2 \mathrm{kaBP}$ event in foraminifer isotope records from the Indus River delta in the Arabian Sea, Clim. Past, 15, 73-90, https://doi.org/10.5194/cp-15-73-2019, 2019.

Hartmann, K. and Wünnemann, B.: Hydrological changes and Holocene climate variations in NW China, inferred from lake sediments of Juyanze palaeolake by factor analyses, Quaternary Int., 194, 28-44, https://doi.org/10.1016/j.quaint.2007.06.037, 2009.

Haug, G. H., Hughen, K. A., Sigman, D. M., Peterson, L. C., and Röhl, U.: Southward migration of the intertropical convergence zone through the Holocene, Science, 293, 1304-8, https://doi.org/10.1126/science.1059725, 2001.

Hughen, K. A., Overpeck, J. T., Peterson, L. C., and Trumbore, S.: Rapid climate changes in the tropical Atlantic region during the last deglaciation, Nature, 380, 51-54, https://doi.org/10.1038/380051a0, 1996.

Jones, C. and Carvalho, L. M. V.: Active and break phases in the South American monsoon system, J. Climate, 15, 905-914, https://doi.org/10.1175/15200442(2002)015<0905:AABPIT>2.0.CO;2, 2002.

Isola, I., Zanchetta, G., Drysdale, R. N., Regattieri, E., Bini, M., Bajo, P., Hellstrom, J. C., Baneschi, I., Lionello, P., Woodhead, J., and Greig, A.: The $4.2 \mathrm{ka}$ event in the central Mediterranean: new data from a Corchia speleothem (Apuan Alps, central Italy), Clim. Past, 15, 135-151, https://doi.org/10.5194/cp15-135-2019, 2019.

Jonkers, H. M., Ludwig, R., Wit, R., Pringault, O., Muyzer, G., Niemann, H., Finke, N., and Beer, D.: Structural and functional analysis of a microbial mat ecosystem from a unique permanent hypersaline inland lake: La Salada de Chiprana; (NE Spain), FEMS Microbiol. Ecol., 44, 175-189, https://doi.org/10.1016/S01686496(02)00464-6, 2003.

Kaniewski, D., Marriner, N., Cheddadi, R., Guiot, J., and Van Campo, E.: The $4.2 \mathrm{kaBP}$ event in the Levant, Clim. Past, 14, 1529-1542, https://doi.org/10.5194/cp-14-1529-2018, 2018.
Kathayat, G., Cheng, H., Sinha, A., Berkelhammer, M., Zhang, H., Duan, P., Li, H., Li, X., Ning, Y., and Edwards, R. L.: Evaluating the timing and structure of the $4.2 \mathrm{ka}$ event in the Indian summer monsoon domain from an annually resolved speleothem record from Northeast India, Clim. Past, 14, 18691879, https://doi.org/10.5194/cp-14-1869-2018, 2018.

Kushnir, Y. and Stein, M.: North Atlantic influence on 19th20th century rainfall in the Dead Sea watershed, teleconnections with the Sahel, and implication for Holocene climate fluctuations, Quaternary Sci. Rev., 29, 3843-3860, https://doi.org/10.1016/j.quascirev.2010.09.004, 2010.

Laslandes, B., Sylvestre, F., Sifeddine, A., Turcq, B., Albuquerque, A. L. S., and Abrão, J.: Enregistrement de la variabilité hydroclimatique au cours des 6500 dernières années sur le littoral de Cabo Frio (Rio de Janeiro, Brésil), CR Geosci., 338, 667-675, https://doi.org/10.1016/j.crte.2006.05.006, 2006.

Laverock, B., Gilbert, J. A., Tait, K., Osborn, A. M., and Widdicombe, S.: Bioturbation: impact on the marine nitrogen cycle, Biochem. Soc. T., 39, 315-320, https://doi.org/10.1042/BST0390315, 2011.

Ledru, M. P., Salgado-Labouriau, M. L., and Lorscheitter, M. L.: Vegetation dynamics in southern and central Brazil during the last 10,000 yr BP, Rev. Palaeobot. Palyno., 99, 131-142, https://doi.org/10.1016/S0034-6667(97)00049-3, 1998.

Lemos, R. M. T.: Estudo das fácies deposicionais e das estruturas estromatolíticas da Lagoa Salgada - Rio de Janeiro, Dissertação (Mestrado em Geologia e Geofísica Marinha) - Universidade Federal Fluminense, Niterói, 122 f., 1995.

Lessa, D. V. O., Venancio, I. M., dos Santos, T. P., Belem, A. L., Turcq, B. J., Sifeddine, A., and Albuquerque, A. L. S.: Holocene oscillations of Southwest Atlantic shelf circulation based on planktonic foraminifera from an upwelling system (off Cabo Frio, Southeastern Brazil), Holocene, 26, 1175-1187, https://doi.org/10.1177/0959683616638433, 2016.

Li, H., Cheng, H., Sinha, A., Kathayat, G., Spötl, C., André, A. A., Meunier, A., Biswas, J., Duan, P., Ning, Y., and Edwards, R. L.: Hydro-climatic variability in the southwestern Indian Ocean between 6000 and 3000 years ago, Clim. Past, 14, 1881-1891, https://doi.org/10.5194/cp-14-1881-2018, 2018.

Ludwig, R., Al-Horani, F. A., de Beer, D., and Jonkers, H. M.: Photosynthesis-controlled calcification in a hypersaline microbial mat, Limnol. Oceanogr., 50, 1836-1843, https://doi.org/10.4319/lo.2005.50.6.1836, 2005.

Martin, L. and Suguio, K.: Variation of coastal dynamics during the last 7000 years recorded in beach-ridge plains associated with river mouths: example from the central Brazilian coast, Palaeogeogr. Palaeocl., 99(1-2), 119-140, https://doi.org/10.1016/0031-0182(92)90010-3, 1992.

Megens, L., van der Plicht, J., de Leeuw, J., and Smedes, F.: Stable carbon and radiocarbon isotope compositions of particle size fractions to determine origins of sedimentary organic matter in an estuary, Org. Geochem., 33, 945-952, https://doi.org/10.1016/S0146-6380(02)00060-8, 2002.

Meyers, P. A.: Organic geochemical proxies of paleoceanographic, paleolimnologic, and paleoclimatic processes, Org. Geochem., 27, 213-250, https://doi.org/10.1016/S0146-6380(97)00049-1, 1997.

Nagai, R. H., Sousa, S. H. M., Burone, L., and Mahiques, M. M.: Paleoproductivity changes during the Holocene in the inner shelf 
of Cabo Frio, southeastern Brazilian continental margin: Benthic foraminifera and sedimentological proxies, Quaternary Int., 206, 62-71, https://doi.org/10.1016/j.quaint.2008.10.014, 2009.

Nagai, R. H., Martins, M. V. A., Burone, L., Wainer, I. E. K. C., Mello e Sousa, S. H., Figueira, R. C. L., Bícego, M. C., Alves, D. P. V., Dias, J. M. A., and Mahiques, M. M.: In-Phase InterHemispheric Changes in Two Upwelling Regions: the Southeast Brazilian and NW Iberian Margins, J. Sediment. Environ., 1, $43-$ 67, https://doi.org/10.12957/jse.2016.21463, 2016.

Perşoiu, A., Ionita, M., and Weiss, H.: Atmospheric blocking induced by the strengthened Siberian High led to drying in west Asia during the $4.2 \mathrm{ka} \mathrm{BP}$ event - a hypothesis, Clim. Past, 15, 781-793, https://doi.org/10.5194/cp-15-781-2019, 2019.

Pessenda, L. C. R., Gouveia, S. E. M., Aravena, R., Boulet, R., and Valencia, E. P. E.: Holocene fire and vegetation changes in southeastern Brazil as deduced from fossil charcoal and soil carbon isotopes, Quaternary Int., 114, 35-43, https://doi.org/10.1016/S1040-6182(03)00040-5, 2004.

Rossetti, D. F., Cohen, M. C. L., and Pessenda, L. C. R.: Vegetation Change in Southwestern Amazonia (Brazil) and Relationship to the Late Pleistocene and Holocene Climate, Radiocarbon, 59, 69-89, https://doi.org/10.1017/RDC.2016.107, 2017.

Salomons, W. and Mook, W.: Field observations of the isotopic composition of particulate organic carbon in the southern North Sea and adjacent estuaries, Mar. Geol., 41, M11-M20, https://doi.org/10.1016/0025-3227(81)90079-7, 1981.

Schulz, H. D. and Zabel, M.: Marine Geochemistry, SpringerVerlag, Berlin, 1999.

Scuderi, L. A., Yang, X., Ascoli, S. E., and Li, H.: The $4.2 \mathrm{ka} \mathrm{BP}$ Event in northeastern China: a geospatial perspective, Clim. Past, 15, 367-375, https://doi.org/10.5194/cp-15-367-2019, 2019.

Silva, L. H. da S., Alves, S. A. P. M. N., Magina, F. C., and Gomes, S. B. V. C.: Composição cianobacteriana e química dos estromatólitos da lagoa Salgada, Neógeno do estado do Rio de Janeiro, Brasil, Geol. USP. Série Científica, 13, 95-106, https://doi.org/10.5327/Z1519-874X2013000100006, 2013.

Silva e Silva, L., Iespa, A. A. C., Damazio, C. M., Gomes, S. B. V. C., and Alves, S. A. P. M. N.: Confronto entre estruturas estromatolíticas domais (composição cianobacteriana) das lagoas Pernambuco e Salgada, Brasil, Rev. Geol., 18, 159-165, 2005.

Silva e Silva, L., Iespa, A. A. C., and Damazio, C. M.: Composição dos Estromatólitos Estratiformes da Lagoa Salgada, Rio de Janeiro, Brasil, Anuário do Inst. Geociências - UFRJ, 31, 4249, 2008.
Staubwasser, M. and Weiss, H.: Holocene Climate and Cultural Evolution in Late Prehistoric-Early Historic West Asia, Quaternary Res., 66, 372-387, https://doi.org/10.1016/j.yqres.2006.09.001, 2006.

Suguio, K., Martin, L., Bittencourt, A. C. S. P., Dominguez, J. M. L., Flexor, J.-M., and Azevedo, A. E. G.: Flutuações do nível relativo do mar durante o Quaternário superior ao longo do litoral brasileiro e suas implicações na sedimentação costeira, Rev. Bras. Geociências, 15, 273-286, 1985.

Tapia, P. M., Fritz, S. C., Baker, P. A., Seltzer, G. O., and Dunbar, R. B.: A late quaternary diatom record of tropical climatic history from Lake Titicaca (Peru and Bolivia), Palaeogeogr. Palaeocl., 194, 139-164, https://doi.org/10.1016/S0031-0182(03)00275-X, 2003.

Thunell, R. C., Qingmin, M., Calvert, S. E., and Pedersen, T. F.: Glacial-Holocene Biogenic Sedimentation Patterns in the South China Sea: Productivity Variations and Surface Water $p \mathrm{CO}_{2}$, Paleoceanography, 7, 143-162, https://doi.org/10.1029/92PA00278, 1992.

Wang, Y.: The Holocene Asian Monsoon: Links to Solar Changes and North Atlantic Climate, Science, 308, 854-857, https://doi.org/10.1126/science.1106296, 2005.

Weiss, H., Courty, M.-A., Wetterstrom, W., Guichard, F., Senior, L., Meadow, R., and Curnow, A.: The Genesis and Collapse of Third Millennium North Mesopotamian Civilization, Science, 261, 995-1004, https://doi.org/10.1126/science.261.5124.995, 1993.

Xu, H., Ai, L., Tan, L., and An, Z.: Stable isotopes in bulk carbonates and organic matter in recent sediments of Lake Qinghai and their climatic implications, Chem. Geol., 235, 262-275, https://doi.org/10.1016/j.chemgeo.2006.07.005, 2006.

Zanchetta, G., Regattieri, E., Isola, I., Drysdale, R. N., Bini, M., Baneschi, I., and Hellstrom, J. C.: The so-called " 4.2 event" in the central mediterranean and its climatic teleconnections, Alp. Mediterr. Quat., 29, 5-17, 2016.

Zhou, C., Wong, K., and Zhao, J.: Coastal Wetland Vegetation in Response to Global Warming and Climate Change, in: Sea Level Rise and Coastal Infrastructure, InTech Open, 1, p. 13, https://doi.org/10.5772/intechopen.73509, 2018. 